\title{
Environmental Justice in Western Europe
}

\author{
Heike Köckler (Department of Community Health, hsg Bochum, Germany) \\ Severiné Deguen (Department of Epidemiology and Biostatistics, Rennes, France) \\ Andrea Ranzi (Regional Centre for Environment and Health, ARPAE Emilia-Romagna, Modena, Italy) \\ Anders Melin (Malmö University, Malmö, Sweden) \\ Gordon Walker (Lancaster Environment Centre, Lancaster University, Lancaster, Great Britain)
}

\section{Introduction}

Western Europe has a long tradition of dealing with interlinkages between social inequity, environmental quality and health outcomes on the one hand and the idea of a just city on the other hand. Especially during the periods of industrialisation and urban growth in the $19^{\text {th }}$ and $20^{\text {th }}$ centuries, these topics were of major concern (Mosse \& Tugendreich 1994) and led to alternative concepts of more just cities that included environmental quality for the working class. Some of the most famous conceptual notions of this form were the Garden City Movement in the UK and elsewhere (Howard 1902) and the Athens Charta of Le Corbusier and others (CIAM 1933). The Athens Charta as a guiding principle for remaking cities was motivated, amongst others, by the idea of health promotion for all. Core-elements of the Athens Charta are the overall goal of a functional city, a guaranteed minimum of solar exposure in all dwellings, access to parks and protection of dwellings from emissions. Most of these discourses were clouded by World War II and the rebuilding activities afterwards. Despite of the overall goal of health promotion the legacy of planning a functional city according to the Athens Charta contributes to many of the urban problems we still face today (Jacobs 1961).

Following the 1992 United Nations Earth Summit in Rio de Janeiro and related activities, sustainable development has become an active and influential discourse in Europe. As sustainable development calls for an integration of the social and environmental dimensions of development including the vision of a more just world, there was a clear resonance with the term environmental justice which began to be used in the mid-1990s in different Western European countries. There was some flow of influence from the US, but also much reinterpretation into an agenda that connected to Europespecific concerns and also considered the global dimensions of environmental justice (Stephens et al. 2001; Walker 2012; Diefenbacher 2001). Since then the discourse on environmental justice has been driven forward in Western Europe by relatively few people, academics mainly and some activists. Its status and meaning varies considerably from country to country, so that some distinctive national environmental justice discourses have emerged. As such a common identity of a Western European 'environmental justice community' does not exist. This might be due to both the mix of national identities and the ongoing evolution of European identity as a whole, including the expansion of the EU to Eastern Europe. Therefore in this chapter countries from Western Europe that are not part of the EU, such as Switzerland, are considered, while other EU-member countries, such as Poland and Hungary, are dealt with in Chapter 51 on Eastern and Central Europe. 
In this chapter we aim to provide an overview of the variety of topics and methods that characterise the evolving set of environmental justice discourses in Western Europe. In acknowledging the variety of discourses we do not therefore judge whether a study, program or any other kind of contribution is an environmental justice contribution or not. Instead we include studies and activities in this chapter that are stated as dealing with environmental justice by their protagonists. In broad terms, though, we see environmental justice as more than an analytical concept integrating social and environmental factors. It is about a positive vision for a more just world and it involves making claims about "how things ought to be" (normative), "how things are" (descriptive) and "why things are how they are" (explanatory) (Walker 2012, 40-41). Based on such claim-making, interventions can be derived in accordance with the vision of environmental justice that is put forward (Bolte et al. 2012).

In the first section of this chapter the range of discourses on environmental justice in Western Europe is introduced through an overview that focuses on the forms of concern and normativity that have been central to environmental justice claim-making. This is followed by an overview of similarities and differences in methodological approaches and results regarding distributional inequalities, based on selected studies. In the second section the role of spatial and environmental planning and the involvement of citizens in planning processes and access to information will be dealt with, focusing therefore on questions of procedural justice. Decision making in this context will be focused on the specific context of implementation of the Aarhus Convention in the European Union. In the final section we take the dimension of future generations into account and discuss the relation between environmental justice and sustainability using the example of the energy sector and ways of dealing with nuclear power.

\section{Discourses of Environmental Justice in Western Europe}

In most Western European countries, such as the Netherlands, Germany, France and Italy, the environmental justice discourse has been initiated by people concerned with health inequalities, identifying the physical environment as one of the relevant predictors of disparities in health (see Chapter 26). To these actors the concept of environmental justice has been valued due to its multidimensional and intervention-oriented approach to providing new answers for the problem of increasing health inequality. Environmental justice therefore is mainly seen as an explanatory concept adding more determinants to explaining health inequality. The overall normative sense of 'how things ought to be' is a distributional one of wanting to see health inequalities significantly reduced (Kruize et. al. 2014; WHO 2010; WHO 2012; Mielck \& Bolte 2004).

In the UK in particular, there was a parallel and interconnected emergence of interest from the mid 1990s in applying notions of inequality and injustice to the environment. This included environmental groups, particularly Friends of the Earth (FoE), academics within geography, sociology, social policy, planning and health, and to some degree policy makers (Walker et al. 2003; Fairburn et al. 2005; Walker et al. 2007, Poustie 2004). In other European countries the discourse on environmental justice has also now extended into disciplines beyond public health and epidemiology. For example, in Germany urban and environmental planning now plays an active role in the discourse (Böhme \& Bunzel 2014; Köckler 2014) as well as sociology (Elvers 2011), while in Sweden planning scientists and environmental lawyers shaped the environmental justice discourse from the very beginning (Ebbeson 2002; Bradley et al. 2008; Gunnarson-Östling 2011). In France the first academic papers were from a 
political science perspective (Laurent 2014), whilst in Switzerland early research was from a sociological perspective (Diekmann \& Meyer 2011). Publications and website materials on environmental justice are now available in an increasing number of countries, conferences on environmental justice have been held and environmental justice is more and more part of the scientific conferences of disciplinary associations.

As discussed in more detail below, in several countries, studies have been carried out that have identified spatial patterns that demonstrate forms of environmental distributional injustice, mainly through combining poverty and deprivation data with indicators of pollution, risk or environmental amenities. However, this has not always been the case, as some studies have found spatial patterns that do not show distributional injustice, or have produced contradictory results depending on methods applied.

As discourses of environmental justice in Western Europe are often closely connected to the sustainability discourse, they have included in some parts a global view, putting climate adaptation and mitigation and therefore energy issues firmly on the justice agenda. In several countries an older discourse on energy poverty is now discussed as an environmental or energy justice issue (see Chapter 31). For example, environmental justice has continued to be a significant campaigning theme for FoE in England, Wales and Scotland, and has been applied in various ways to both domestic and international issues. Climate justice has become particularly important as a theme for the mobilisations of many groups on climate change, and has featured particularly in opposition to fracking, new airport proposals and in debates around the major climate change negotiations. In parallel with political framings there has also been much new and continuing work on climate and energy justice themes (Bickerstaff et al. 2013).

The engagement with and role of government and civil society in relation to environmental justice has been quite differentiated across Europe. In the UK in the mid-1990s the then Labour government was particularly concerned with issues of inequality and exclusion, and there was an opportunity for those newly campaigning around environmental justice (such as FoE) to achieve political influence by tying into these concerns. This was particularly the case in Scotland, where recent devolution provided the context for environmental justice becoming a key theme both for the Scottish Government and FoE Scotland (Dunion 2003; Scandrett 2007). The governmental interest in environmental justice has though markedly declined in the UK in recent years, reflecting both changes in government and severe cuts to the funding and responsibilities of government departments and agencies.

In Germany and France the level of public and governmental interest is in contrast increasing. In Germany there are various public financed programmes dealing with environmental justice, especially in the field of urban planning (Böhme \& Bunzel 2014). The Federal Environmental Agency has promoted environmental justice for several years by hosting conferences and funding projects, including some carried out by an environmental NGO, Deutsche Umwelthilfe. Other agencies started to become active in 2015. On the level of the federal states Berlin and North-Rhine Westphalia are the most active. In Berlin an environmental justice analysis has been carried out and is integrated into the spatial planning system. In North Rhine Westphalia environmental justice was mentioned in the coalition agreement from 2012 between the social democrat and green party, and it is intended to be followed into an action plan. 
In Sweden within politics and grassroots movements, environmental justice has been increasingly discussed by actors such as WWF (World Wildlife Fund), Naturskyddsföreningen, other left wing oriented grassroot organisations and also, notably, addressed by some of the political parties such as the Left Party and the Green Party. Nonetheless outside of these examples, in most Western European countries environmental justice is not at all significant within the agenda of parties or governments.

Therefore in Western Europe environmental justice is mainly driven by stakeholders in academic science and to some degree in public administration. In contrast to the US there has never been a strong citizen based environmental justice movement. This may be because the environmental movement in most of Western Europe remains the preserve largely of leaders and members that are white and middle class, rather than involving minority ethnic populations. However, a thorough systematic explanation remains to be undertaken.

\section{Studies of distributional environmental injustice}

Environmental justice has a clear spatial dimension. Here inequality is found in patterns of 'how things are', both in terms of the spatial distribution of access to environmental resources and exposure to environmental health determinants. Both, access and exposure, require a relevant coincidence in proximity and time between an individual and a certain state of the environment. Table 1 gives an overview of selected Western European studies on distributional inequality. These have been chosen to represent the work undertaken in different countries and to demonstrate the range of factors and methods that have been included.

$<$ table 1 here $>$

The $2^{\text {nd }}$ column of Table 1 , listing the factors which are included in the analyses, shows a common ground of combining together social and environmental parameters. Some studies additionally integrate health outcome factors (Michelozzi et al. 2005; Fecht et al. 2015; Kihal-Talantikite et al $2013 \mathrm{a}$ and $\mathrm{b}$ ), whilst focusing on the relation between social status and specific environmental stressors, such as waste facilities (Martuzzi et al. 2010). For the social dimension different indices are applied. While in the UK the index of multiple deprivation is available nationwide, in Germany the index used for the Berlin study is a city specific approach. This is an example of limited comparability between the different studies. A range of environmental dimensions have been studied, with air quality (see Chapter 26) often the focus, including examining the distributional impact of policy interventions - such as research in Italy that evaluated the impact of the introduction of a lowemissions zone on social inequalities (Cesaroni et al. 2012). Especially in the field of noise and air quality, some of the relevant indicators are comparable, at least amongst EU-member states, due to needing to follow the same legal requirements. These data also have a fairly good availability, enabling Fecht et al. (2015) to compare associations between air pollution and socioeconomic characteristics of neighborhoods in England and the Netherlands. Environmental goods, in particular green- or open-space, are also dealt with in European studies, such as the Berlin and Lyon cases shown in Table 1.

Methodologically a variety of approaches have been applied. The Berlin study is a showcase for an assessment of multiple burdens, following a simple summative approach. Lalloué et al. (2015) 
applied a cumulative environmental index using a data mining approach (see also Chapter 22). The UK-study by Briggs et al. (2008) is distinctive, in part, being concerned with identifying confounding factors affecting epidemiological study results.

The results of the studies are varied, as their short description in Table 1 shows. The French study on $\mathrm{NO}_{2}$ shows differences in social inequality and $\mathrm{NO}_{2}$ exposure between Paris and other French cities. The Berlin case shows that the most deprived people have to face more burdens than others. Fecht et al. (2015) show inequalities in the UK and the Netherlands exhibit some regional variation; especially identifying urban areas as most affected by distributional inequality concerning air quality. The study by Richardson et al. (2010) is an example that goes beyond just the description of 'how things are', in trying to isolate the processes at work in generating inequalities. They examine alternative explanations asking which came first: local deprivation or the siting of waste landfill sites?

While most of the studies have been undertaken for analytical reasons only, the environmental justice project in Berlin (BfS et al. 2011) is an example of a study that has been conducted by the administration of Berlin Senate with the support of universities. It is meant to be actively used in local decision-making and has been integrated as a specific report in the legal land use zoning plan. Similarly the results of the study on French metropolitan areas (Padilla et al. 2014) were integrated in the final report of the second French national plan for environmental health.

\section{The participatory dimension of environmental justice}

Meaningful participation of all people in decision-making processes, or procedural environmental justice (see Chapter 9), is seen by different Western European authors as an important element of environmental justice (e.g. Ebbesson 2002, Bradley at al 2008; Bolte et al. 2012; Köckler 2014). Todd and Zografos $(2005 ; 485)$ provide the following definition in a paper on indicators for environmental justice in Scotland: "Procedural justice: this is concerned with how and by whom decisions are made, and encompasses participation and legitimacy as common concepts." In their work, which includes a participatory process to weigh between different indicators, it is significant that Scottish community environmental activists weighed procedural justice higher than other dimensions of environmental justice.

The Western European urban and environmental planning system has a crucial influence on the distribution of land uses including the location and design of infrastructure (streets, landfills, housing, parks etc.). Correspondingly decisions in urban and environmental planning influence situations of distributional injustice (see Chapter 36). These decisions are prepared by the governmental administration and taken by local parliaments, legitimated through democratic elections, or by the administrative body depending on the legal framework that applies. In urban and environmental planning the participation of the public is implemented within different decision making procedures. A number of studies in Western Europe have focused on procedural justice questions. For Sweden, Bradley et al. (2008) examine the relevance of the discursive dimensions of justice. They ask who is influential in a discourse defining justice for urban planning. Poustie (2004) explores, in a report for the Scottish Department of the Environment, the extent to which it can take account of environmental justice within its current legislative framework. Poustie identifies considerable rights of public participation in the domestic environmental law framework, but points out that there has 
been little research into their effectiveness from the perspective of those in communities disproportionately affected by pollution. Strelau and Köckler (2015) carried out a study on the perspectives on environmental justice of employees in German local environmental agencies. They come to the conclusion that environmental justice is hardly an issue for those environmental agencies, being part of their investigation. One reason why these environmental agencies do not consider environmental justice as an issue is that within the general public there has been neither debate on the issue nor recognition of the concept of environmental justice. Both reasons can be linked to procedural injustice, because the social dimension of air quality in urban areas, which is a matter of environmental justice (see table 1 ), was not integrated into the agencies' decision making. Therefore no relevance was given to environmental justice by the environmental agencies considered in this analysis.

Across Europe the general rights of the public (individuals and their associations) were strengthened by the "Convention on Access to Information, Public Participation in Decision-Making and Access to Justice in Environmental Matters" (see also discussion in Chapter 9). This convention was signed by members of the United Nations Economic Commission for Europe in Aarhus Denmark in 1998 and is referred to as the Aarhus Convention. In 2003 the European Union adopted in two Directives core elements of the Aarhus Convention. They had to be implemented in the national law of the EU Member States by 2005. Also non EU-member states of Western Europe have adopted this convention: Norway in 2003, Iceland in 2011 and Switzerland in 2013. The potential of Aarhus for taking forward environmental justice was discussed from its very beginning (Ebbesson 2002).

Beyond doubt the implementation of the Aarhus Convention has led to improvements in the right to participation in decision-making processes, but the right to participation itself does not guarantee that this right will be used in practice by all people equally. People with fewer resources typically use the right to participation less than others (Köckler 2014). In a case study of the city of Bristol in England, Bell (2008) shows that though people are interested and active in environmental matters, their achievements are limited largely as a result of the asymmetry of power in environmental decision-making partnerships. This shows the complexity of procedural environmental justice: it is not only about the right to participate and the capabilities of participants, especially of deprived communities; it is also about the ability of those in power to integrate stakes in decision-making procedures to guarantee meaningful involvement for all.

\section{Taking future generations into account}

As already noted in Western Europe there are often strong connections made between sustainability and environmental justice (see Chapter 14), reflecting wider calls for how these discourses should be brought together, including within the notion of 'just sustainability' (Agyeman \& Evans 2004, 155164). Justice between contemporary and future generations is a significant aspect of sustainability. Our Common Future defines sustainable development as "development that meets the needs of the present without compromising the ability of future generations to meet their own needs" (World Commission on Environment and Development 1987). It can be argued therefore that intergenerational justice is an important part of environmental justice, although it is seldom recognized as such (see also Chapter 13 on human rights approaches). 
Questions about what responsibility we have towards future generations have been especially important within debates about nuclear energy and nuclear waste management in Western Europe, as a consequence of the fact that nuclear waste will remain dangerous for future generations at least 100,000 years into the future and has to be stored safely (Rüdig 1990; Sovacool 2013) - see also Chapter 31. To provide specific examples, here we will focus on how the issue of intergenerational justice has been acknowledged within the debate on nuclear energy in two countries in Western Europe: Germany and Sweden. In Germany the first nuclear power station was opened in 1962 and during the next two decades over 30 additional power plants were built. Although the majority of the population accepted nuclear energy, there were also more critical voices. When the German Green Party entered the parliament for the first time in 1983, ethical discussions concerning nuclear energy became more common. One important theme was what responsibility we have to protect the planet for the sake of future generations (Schreurs 2014, 11-13).

The Fukushima accident in 2011 led to an increased concern about ethical issues, and German Chancellor Angela Merkel decided to temporarily shut down the seven oldest nuclear power plants and another one that had technical problems. She also established an ethics commission to analyse the ethical dimensions of Germany's energy production, which published its report on the 30th of May 2011. The fact that Merkel established a commission with a special focus on ethical issues is quite remarkable since the political discourse on environmental problems generally emphasizes technical and economic issues much more than ethical ones. Soon after the publication of the Commission's report the government decided to permanently shut down the eight nuclear power plants and to set out a schedule for the phase-out of the remaining nine, according to which the last nuclear power plants will be shut down in 2022 (Schreurs 2014). The report states that current generations have a clear responsibility to ensure future living conditions, in that whilst use of nuclear energy may benefit us now, it will at the same time lead to risks for future generations (Ethics Commission for a Safe Energy Supply 2011).

In Sweden the first commercial reactor started operation in 1972, but political opinion soon switched against nuclear energy. In 1980 the Swedish parliament made the decision that the twelve reactors that were by then operating, under construction or planned should be allowed to continue working for their technical length of life, which was then assumed to be 25 years, but no more new stations should be built. The Swedish nuclear energy epoch should therefore be over by 2010 . However, the decision to phase-out nuclear energy by 2010 was then cancelled in 2009, and at least so far, the Fukushima accident has not led again to any significant shift in this policy (Kolare et. al. 2016). Through these ongoing debates, questions about responsibilities to future generations have been an important theme within the Swedish mass media (Anshelm 2000). Moreover, a large number of official Swedish political documents on nuclear energy and nuclear waste management, such as private members' motions and public reports, mention the issue of intergenerational justice. A Swedish government report (Statens Offentliga Utredningar /SOU 2013) states, for example, that the fundamental moral principle that underlies the Swedish discussion of nuclear waste management is that each generation should have the right to decide for themselves which technology they want to use for managing nuclear waste, a principle that the report labels as the principle of "intergenerational autonomy". Future generations should have freedom of action. They should be given the same right as current generations to integrity, ethical freedom and responsibility (SOU 2013, 71). 


\section{Conclusion}

Environmental justice in Western Europe can be characterized by several sub-discourses that are only rarely integrated together. They extend from a focus on distributional analysis dealing with healthy living conditions, to concerns for procedural justice and into energy related topics including energy poverty as well as the intergenerational ethical issues particularly raised by Europe's evolving and differentiated relationship with nuclear power. This variety reflects the different interests that there are in focusing on environmental justice (some more analytical, some more normative), disciplinary engagements and limitations and the specific social, political and geographical situations of the nations of Western Europe.

Studies on the social distribution of environmental goods and bads do show particular patterns of inequality, but simple generalisations across the European space are problematic. Distributional environmental justice analysis in Western Europe is a topic mainly focused on urban agglomerations and has been based on a variety of environmental and social indicators. Therefore the direct comparability of study results is not given. Participation in environmental decision making has been the focus of analysis in many different European contexts, demonstrating that whilst there are established guarantees of participation within legal frameworks (through the Aarhus convention in particular), these rights do not necessarily mean that opportunities will be acted on or be meaningful in practice, particularly for more marginal communities.

Environmental justice, as an explicit term, remains in Europe largely a topic for study, an analytical framework, and to some extent, it has also been adopted into policy and planning discourses and practices. Although there are examples of environmental groups taking up environmental justice as a campaigning theme in Western Europe there is no integrated grass-roots based environmental justice movement. Typically communities who are affected by actual or expected negative consequences of environmental harm or access to environmental goods, are not mobilizing under a collective justice discourse - except in relation to climate justice campaigning where questions of global inequalities and responsibilities are predominant. However, as demonstrated by the intergenerational ethical questions that have been important to debates over nuclear power, this does not mean that matters of justice, fairness and equity in relation to the environment do not figure within European politics. From the local to the international scale normative justice concerns are part of environmental debate and the potential remains for them to become galvanised into a more explicit justice agenda, informed by the growing body of academic analysis of inequalities in distributional patterns and processes of decision-making.

To enhance the body of academic analysis on environmental justice in Western Europe we see the need for further research on a range of topics including: a) the development of comparable crosscountry study designs for analyzing patterns of distributional justice; b) analysis of dimensions of procedural injustice relating to the citizen engagement in different contexts across Western Europe, recognizing that these may be distinct from those in other regions in the world; $c$ ) integration of justice into the guiding principles of environmental politics, learning in particular from the domains of energy and climate protection and adaptation where justice ideas have become more established d) examination of how the use of legal provisions does or does not support the making of environmental justice claims, given evidence that those treated unjustly are often not able to get effective access to the legal system and e) further analysis of cases where the emergence of 
environmental injustice claims and discourses do not emerge where they might be expected to, seeking to understand the underlying dynamics and politics that are at work.

(Acknowledgement: Thanks to Karolina Isaksson Swedish National Road and Transport Research Institute (VTI) for detailed information on Sweden) 


\section{References}

Agyeman, J. \& Evans, B. (2004). "Just sustainability: the emerging discourse of environmental justice in Britain?" The Geographical Journal, vol. 170, no. 2, pp. 155-164.

Anshelm, J. (2000). Mellan frälsning och domedag: Om kärnkraftens politiska idéhistoria i Sverige 1945-1999. Stockholm: Brutus Östlings Bokförlag Symposion 2000.

Bell, K (2008). "Achieving Environmental Justice in the United Kingdom: A Case Study of Lockleaze." Environmental Justice, vol. 1, no. 4, pp. 203-210.

BfS (Bundesamt für Strahlenschutz) (2011). Special Issue II - Environmental Justice. Federal Office for Radiation Protection (BfS), Federal Institute for Risk Assessment (BfR), Robert Koch Institute (RKI), Federal Environment Agency (UBA).

Bickerstaff, K., Walker G. \& Bulkeley, H. (eds) (2013). Energy Justice in a Changing Climate: social equity and low carbon energy, Zed, London.

Böhme, C. \& Bunzel, A. (2014). „Umweltgerechtigkeit im städtischen Raum: Expertise ,Instrumente zur Erhaltung und Schaffung von Umweltgerechtigkeit'."Berlin.

Bolte, G., Bunge, C., Hornberg, C., Köckler, H. \& Mielck, A. (Eds.) (2012). „Umweltgerechtigkeit: Chancengleichheit bei Umwelt und Gesundheit: Konzepte, Datenlage und Handlungsperspektiven." 1st ed., Verlag Hans Huber, Bern.

Bradley, K., Gunnarsson-Östling, U., Isaksson, K. (2011). “Exploring environmental justice in swedenHow to improve planning for environmental sustainability and social equity in an 'ecoFriendly' context". Justice, Equality + Sustainability, MIT Journal of Planning.

Briggs, D., Abellan, J.J. and Fecht, D., (2008). „Environmental inequity in England: Small area associations between socio-economic status and environmental pollution." Social Science and Medicine, vol. 67 no.10, pp. 1612-1629.

Congress Internationaux d'Architecture moderne (CIAM), La Charte d'Athenes or The Athens Charter, 1933. Trans J.Tyrwhitt. Paris, France: The Library of the Graduate School of Design, Harvard University, 1946.

Diefenbacher, H. (2001). Gerechtigkeit und Nachhaltigkeit: Zum Verhältnis von Ethik und Ökonomie. Darmstadt, Wiss. Buchges.

Diekmann, A., Meyer, R., (2011). "Democratic Smog? An Empirical Study on the Correlation Between Social Class and Environmental Pollution." UMID 2/2011, Special Issue Environmental Justice II, pp. 72-77.

Dunion, K., (2003). Troublemakers: The Struggle for Environmental Justice in Scotland. Edinburgh: Edinburgh University Press.

Ebbesson, J. (Ed.) (2002). Access to Justice in Environmental Matters in the EU. The Hague: Kluwer Law International.

Elvers, H.-D. (2011). „Umweltgerechtigkeit.“ Handbuch Umweltsoziologie. M. Groß. Wiesbaden, VS Verlag für Sozialwissenschaften: 464484. 
Ethics Commission for a Safe Energy Supply (2011). Germany's energy transition - A collective project for the future, Berlin.

Fairburn, J., Walker, G. and Smith, G. (2005) Investigating Environmental Justice in Scotland - Links Between Measures of Environmental Quality and Social Deprivation. Report UE4(03)01. Edinburgh: Scottish and Northern Ireland Forum for Environmental Research.

Fecht D., Fischer P., Fortunato L., Hoek G., de Hoogh K., Marra M., Kruize H., Vienneau D., Beelen R., Hansell A. close (2015). Associations between air pollution and socioeconomic characteristics, ethnicity and age profile of neighbourhoods in England and the Netherlands, Environmental Pollution, vol. 198, pp. 201-210.

Gunnarsson-Östling U. (2011). "Just Sustainable Futures - Gender and Environmental Justice Considerations in Planning", Stockholm.

Howard, E. (1902). Garden cities of to-morrow. London, Swan Sonnenschein \& Co., LTD.

Jacobs, J. (1961). The death and life of great American cities. Random House.

Kihal-Talantikite W., Padilla C., Lalloué B., Gelormini M., Zmirou-Navier D., Deguen S. (2013a).Green space, social inequalities and neonatal mortality in France. BMC Pregnancy Childbirth. 2013 Oct 20;13:191.

Kihal-Talantikite W., Padilla C., Lalloue B., Rougier C., Defrance J., Zmirou-Navier D., Deguen S.. (2013b) An exploratory spatial analysis to assess the relationship between deprivation, noise and infant mortality: an ecological study. Environ Health. Dec 16;12:109.

Köckler, H. (2014). "Environmental Justice - aspects and questions for planning procedures", UVPreport, vol. 28, no. 3+4, pp. 139-142.

Kolare, S., Vedung, E., Lundberg, F.: "Kärnenergifrågan” in the webpage of Nationalencyklopedin (the National Encyclopedia). http://www.ne.se.proxy.mah.se/uppslagsverk/encyklopedi/lång/kärnenergifrågan (assessed 2016-03-15).

Kruize H., Droomers M., Van Kamp I., Ruijsbroek A. (2014). "What Causes Environmental Inequalities and Related Health Effects? An Analysis of Evolving Concepts." Int. J. Environ. Res. Public Health 2014, 11(6), 5807-5827.

Lalloué Benoit, Monnez Jean-Marie, Padilla Cindy, Kihal Wahida, Zmirou-Navier Denis, Deguen Séverine (2015). "Data analysis techniques: a tool for cumulative exposure assessment". J Expo Sci Environ Epidemiol. Mar-Apr;25(2):222-230.

Laurent, É. (2014). "Environmental Inequality in France: A Theoretical, Empirical and Policy Perspective", Analyse \& Kritik, vol. 02/2014, pp. 251-262.

Michelozzi, P, de Donato, F, et al. (2005). "The impact of the summer 2003 heat waves on mortality in four Italian cities." Euro Surveill, vol. 10, no. 7, pp. 161-5. 
Mielck, A.; Bolte, G. (Ed.) (2004). Umweltgerechtigkeit. Die soziale Verteilung von Umweltbelastungen. Juventa.

Mosse M., Tugendreich G. (1994). Krankheit und Soziale Lage. WiSoMed-Verlag; Auflage: 4

United Nations Environment Programme: Our Common Future/World Commission on Environment and Development, Oxford: Oxford University Press 1987, p. 43.

Padilla, Cindy., Kihal-Talantikite, Wahida., Vieira, Veronica., Rossello, Philippe., Le Nir, Géraldine., Zmirou-Navier, Denis., Deguen, Séverine. (2014). "Air quality and social deprivation in four French metropolitan areas--a localized spatio-temporal environmental inequality analysis." Environ Res.

Poustie, M. (2004). Envrionmental Justice in SEPA's Environmental Protection Activities: A Report for the Scottish Environment Protection Agency. Glasgow.

Raddatz, L. and Mennis, J. (2013). "Environmental Justice in Hamburg, Germany", The Professional Geographer, vol. 65 No. 3, pp. 495-511.

Richardson, E.A., Shortt, N.K. and Mitchell, R.J. (2010). "The mechanism behind environmental inequality in Scotland: which came first, the deprivation or the landfill?" Environment and Planning A, vol. 42, pp. 223-240.

Rüdig, W. (1990). Anti-nuclear Movements: A World Survey of Opposition to Nuclear Energy. Essex, Longman.

Scandrett, E. (2007). "Environmental justice in Scotland: policy, pedagogy and praxis." Environmental Research Letters, vol. 2, no.4: 045002.

Schreurs, M.A. (2014). "The Ethics of Nuclear Energy: Germany's Energy Politics after Fukushima”, The Journal of Social Science, vol. 77, pp. 9-29.

SOU (Statens Offentliga Utredningar) (2013). Kunskaps/äget på Kärnavfallsområdet 2013. Slutförvarsansökan under prövning: kompletteringskrav och framtidsalternativ.

Sovacool, B.K. (2013). Energy \& Ethics: Justice and the Global Energy Challenge, London: Palgrave Macmillan.

Stephens, C., Bullock, S. and Scott, A. (2001). Environmental justice: Rights and means to a healthy environment for all. Swindon: ESRC Global Environmental Change Programme.

Walker, G. (2009). "Beyond Distribution and Proximity: Exploring the Multiple Spatialities of Environmental Justice." Antipode vol.41 no.4, pp. 614-636.

Walker, G. (2012). Environmental Justice: concepts, evidence and politics, Routledge, Abingdon.

Walker, G., Burningham, K., Fielding, J., Smith, G., Thrush, D. and Fay, H. (2007). Addressing environmental inequalities: flood risk. Science Report SC020061. Bristol: Environment Agency.

Walker, G., Fairburn, J., Smith, G. and Mitchell, G. (2003). Environmental Quality and Social 
Deprivation Phase II: National Analysis of Flood Hazard, IPC Industries and Air Quality. Bristol, UK: Environment Agency.

WHO (2010). "Environment and health risks: a review of the influence and effects of social inequalities", available at: http://www.euro.who.int/_data/assets/pdf_file/0003/78069/E93670.pdf (accessed 11 January 2012).

WHO (2012), "Environment health inequalities in Europe", available at: http://www.euro.who.int/ data/assets/pdf file/0010/157969/e96194.pdf (accessed 10 March 2015) 